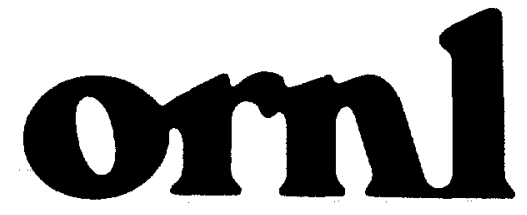

OAK RIDGE

NATIONAL

LABORATORY

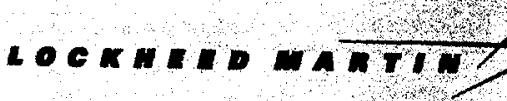

C/ORNL 95-0389

Metals and Ceramics Division

CRADA Final Report

for CRADA Number ORNL 95-0389

GELCASTING POLYCRYSTALLINE ALUMINA

Mark A. Janney

Oak Ridge National Laboratory

Karlene J. Zuk and George C. Wei OSRAM SYLVANIA INC.

Date Published - January 2000

Prepared by the

OAK RIDGE NATIONAL LABORATORY

Oak Ridge, Tennessee 37831

Managed by

LOCKHEED MARTIN ENERGY RESEARCH CORPORATION

for the

U.S. DEPARTMENT OF ENERGY

under contract DE-AC05-960R22464

\author{
APPROVED FOR PUBLIC RELEASE \\ DISTRIBUTION IS'UNLIMITED
}




\title{
Gelcasting Polycrystalline Alumina
}

\author{
Mark A. Janney \\ Metals and Ceramics Division \\ Oak Ridge National Laboratory \\ Karlene J. Zuk and George C. Wei \\ OSRAM SYLVANIA INC.
}

\begin{abstract}
OSRAM SYLVANIA INC. is a major U.S. manufacturer of high-intensity lighting. Among its products is the Lumalux ${ }^{T M}$ line of high-pressure sodium vapor arc lamps, which are used for industrial, highway, and street lighting. The key to the performance of these lamps is the polycrystalline alumina (PCA) tube that is used to contain the plasma that is formed in the electric arc. That plasma consists of ionized sodium, mercury, and xenon vapors. The key attributes of the PCA tubes are their transparency ( $97 \%$ total transmittance in the visible), their refractoriness (inner wall temperature can reach $1200^{\circ} \mathrm{C}$ ), and their chemical resistance (sodium and mercury vapor are extremely corrosive). The current efficiency of the lamps is very high, up to 100 initial lumens per watt. (Compare - incandescent lamps 10-20 lumens per watt, fluorescent lamps $25-90$ lumens per watt.)
\end{abstract}

The purpose of the CRADA was to explore using gelcasting to form translucent PCA tubes for Lumalux ${ }^{\top M}$ lamps. 


\title{
Gelcasting Polycrystalline Alumina*
}

\author{
Mark A. Janney \\ Metals and Ceramics Division \\ Oak Ridge National Laboratory \\ Karlene J. Zuk and George C. Wei \\ OSRAM SYLVANIA INC.
}

\section{Objectives of the CRADA}

The primary purpose of the CRADA was to determine the feasibility of making polycrystalline alumina (PCA) items by gelcasting having sufficient optical quality that they are useful in lighting applications. A second purpose was to determine if that optical quality could be retained in tubes having a complex shape.

OSRAM SYLVANIA INC. currently manufactures PCA tubes by isostatic pressing. This process works well for the shapes that they presently use, but there are several types of arc chambers (mostly OSRAM SYLVANIA INC. proprietary shapes) that are either difficult or impossible to make by isostatic pressing. It is the desire to make these new shapes and sizes of tubes that has prompted OSRAM SYLVANIA Inc.'s interest in gelcasting.

The desired results were PCA tubes of arbitrary shape having excellent optical quality that were suitable for lighting applications. In particular, OSRAM SYLVANIA INC. had several proprietary shapes that they wanted to fabricate.

\section{Were the objectives of the CRADA met?}

The objectives of the CRADA were met.

\footnotetext{
"Research sponsored by the U.S. Department of Energy. Assistant Secretary for Energy Efficiency and Renewable Energy, Office of Industrial Technologies, Advanced Industrial Materials Program, under contract DE-AC05960R22464 with Lockheed Martin Energy Research Corporation.
} 
How did the work done under the CRADA benefit the DOE office that funded the CRADA in pursuing its mission?

The mission of the Advanced Industrial Materials (AIM) Program is to support the development and commercialization of new and improved materials to improve productivity, product quality and energy efficiency in major process industries. The work performed under this CRADA has benefited the AIM program by enabling a new technology, which will improve the energy efficiency of lighting systems.

\section{Technical discussion of the work accomplished}

\section{Scope of Work - Year One}

The technical objective of the CRADA was twofold. The first objective was to demonstrate the ability to make high optical quality gelcast polycrystalline alumina (PCA) tubes similar to those currently used by OSRAM SYLVANIA INC. The second. objective was to demonstrate the ability to make by gelcasting high optical quality PCA in shapes other than those currently used by OSRAM SYLVANIA INC.

Gelcasting is a process for forming ceramic powders. into complex shapes. It is a generic process that has been used to produce complex-shaped ceramic parts from over a dozen different ceramic compositions ranging from alumina-based refractories to high-performance silicon nitride.

We formulated slurries at 45 to 50 volume percent solids using standard gelcasting formulations based on methacrylamide monomer and $\mathrm{N}, \mathrm{N}$ - methylenebisacrylamide crosslinker. These slurries were made using proprietary powder formulations supplied by OSRAM SYLVANIA INC.. Good flow behavior was achieved and viscosities were on the order of $200 \mathrm{cps}$ for the 45 volume percent solids-loaded slurries.

The slurries were successfully cast as thin-walled tubes $(0.36$ inch $O D, 0.030$-inch wall thickness, 1.5 inch long) in molds supplied by OSRAM SYLVANIA INC.. The tubes were fired by OSRAM SYLVANIA INC. using their standard, proprietary firing schedule. Translucent polycrystalline alumina was produced as shown in Figure 1.

We demonstrated the importance of selecting appropriate mold release agents and mold surface finishes to achieving good parts. An extensive study of the interactions of 
mold release agents with mold materials and slurry was conducted. The results of that study are summarized in Table 1. Several features of mold-slurry-release agent interactions become clear after examining Table 1. First, some materials are not good mold materials for precision casting under any circumstances. Neither Lexan $®$ nor Plexiglas $₫$ performed well as mold materials under any of the conditions studied. A thin, ungelled layer always formed at the surface of the mold. Such a layer would cause imperfections in the surface of the parts, which is unacceptable. In contrast, anodized aluminum (both rough and smooth) performed well with all of the release agents except F-57. In general, anodized aluminum performed somewhat better than

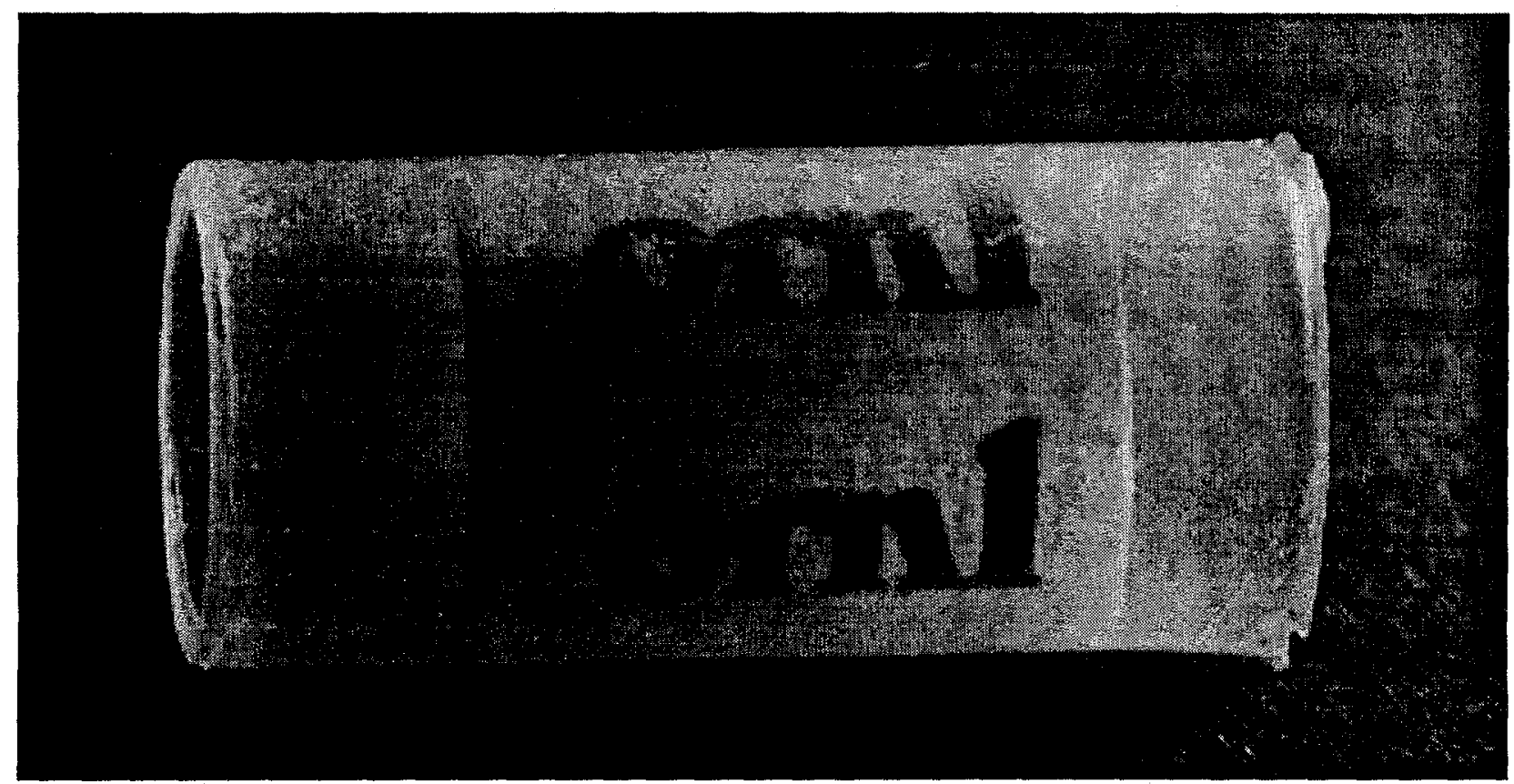

Figure 1. A thin-walled gelcast PCA tube (0.36-inch diameter, 0.030 inch wall thickness) with excellent optical transmission.

non-anodized aluminum. Glass also performed well with the release agents tested in this study. It was further discovered that at least one of the mold releases, Polyester Parfilm, adversely affected the microstructure of the fired polycrystalline alumina tubes. The cause was traced to a minor constituent in the mold release compound that contained titanium dioxide. This underscored the need to be especially careful with potential sources of contamination when gelcasting optical grade ceramic materials. 


\section{Scope of Work - Year Two}

The goal for year two was to further demonstrate that we could gelcast complexshaped tubes of a proprietary design while maintaining high optical transmittance. To accomplish this goal, we investigated several fugitive core strategies. A fugitive core is one that can be used during gelcasting and can then be removed without damaging the gelcast part, even if the part contains re-entrant angles or closed ends. Three approaches were used. The first used a proprietary core material identified by OSRAM SYLVANIA INC. before the CRADA was initiated. Further details about this core will not be described because of the proprietary nature of the topic. The other two approaches used meltable cores made from either pattern wax or a fusible alloy. The pattern wax used was BW 2260 by Blended Waxes, Inc, Oshkosh, WI. It is a blend of waxes, rosin, and other polymeric constituents with isophthalic acid as filler. At ambient temperature $\left(25^{\circ} \mathrm{C}\right)$ the density of the wax is $1.07 \mathrm{~g} / \mathrm{ml}$, and at $85^{\circ} \mathrm{C}$ its density is $0.98 \mathrm{~g} / \mathrm{ml}$. Its melting point is $60^{\circ} \mathrm{C}\left(140^{\circ} \mathrm{F}\right)$. Several fusible alloys were examined including Woods metal and several indium alloys. Both of these approaches were used successfully to make cores and gelcast parts. The procedure involved in gelcasting using removable cores is described below.

A standard gelcasting mix was used for making the complex-shaped tubes. The slurry consisted of 45 volume percent high-purity alumina, one weight percent Darvan 821A dispersant and 15 weight percent hydroxymethylacrylamide in water as the vehicle.

After filling, the molds were placed in a $50^{\circ} \mathrm{C}$ convection oven. Gelation was accomplished at $50^{\circ} \mathrm{C}$ to avoid melting the wax or metal cores. Typically, the molds were enclosed in a high humidity box during gelation to prevent drying of the top of the molded part. We used a covered polyethylene box which had towels saturated with water covering the bottom of the box. About 45 minutes was allowed for gelation. This was not an optimized time; the parts may have gelled in much less time.

After the parts were gelled, the fusible core was removed. The molds were disassembled under flowing de-ionized water. This served to cool the mold and the part, which helped prevent undesired drying. It also tended to eliminate meniscuses, which could make opening the mold somewhat more difficult. After the part was removed from the mold, it was placed in hot de-ionized water $\left(85^{\circ} \mathrm{C}\right)$. It took several minutes for the wax or metal in the part to melt and become fluid enough to flow from the interior of the part. The parts were rinsed repeatedly to make sure that all of the core material was removed from the interior of the part. 
The parts were dried using conventional high humidity drying. First, the part was rinsed in cold, de-ionized water to reduce its temperature to ambient. Then it was placed in a $95 \% \mathrm{RH}$ chamber for 24 hours followed by 24 hours in a $75 \% \mathrm{RH}$ chamber. Final drying was accomplished at ambient conditions on the lab bench.

Firing was done at OSRAM SYLVANIA INC. using standard binder burnout and hightemperature firing techniques. Using meltable core materials such as a wax or a fusible alloy allowed us to produce thin-walled objects in large numbers (over 100 were cast and fired) with excellent physical and optical quality and repeatability.

\section{Inventions}

An invention application has been prepared. The title of the invention is CRADAprotected information. The authors are Mark A. Janney (ORNL), Karlene J. Zuk (OSRAM SYLVANIA INC.), and Jeffrey T. Neil (OSRAM SYLVANIA INC.).

\section{Any plans for future collaboration.}

OSRAM SYLVANIA INC. is considering additional interactions with ORNL based on comparisons between the gelcasting technology and other technologies.

\section{Assessment of commercialization possibilities} Commercialization of the technology appears promising. However, OSRAM SYLVANIA INC. is considering other technologies that might be able to make the same parts. A final decision on commercialization must wait while those technologies are also considered.

\section{Conclusions}

Gelcasting is an effective method for forming high-quality straight and complex PCA tubes. The meltable core approach was demonstrated to be viable for making complex tubes on a lab scale.

Gelcasting could eliminate several geometric constraints in the manufacture of complex-shaped arc tubes. Potential increases in lighting efficiency of over $2 \%$ are predicted. Since lighting consumes about $25 \%$ of all the electricity used in the United States, this would represent a major energy conservation effort. 
Developing a manufacturing approach from the so-far successful laboratory tests will be critical to the successful transfer of this technology. 
Table 1. Mold - mold release interactions for alumina gelcast slurries

(55 vol \% RCHP-DBM, $15 \mathrm{wt} \%$ 4:1 MAM-MBAM solution, $0.5 \mathrm{wt} \%$ Darvan $821 \mathrm{~A}$; initiated at $1 \mu 110 \mathrm{wt} \%$ ammonium persulfate solution and $0.1 \mu \mathrm{l}$ TEMED per g slurry; gelled at $60^{\circ} \mathrm{C}$ for $30 \mathrm{~min}$.)

\begin{tabular}{|c|c|c|}
\hline Substrate Surface & $\begin{array}{l}\text { Mold } \\
\text { Release }\end{array}$ & Interaction \\
\hline \multirow[t]{3}{*}{ Smooth Aluminum } & $F-57^{\star}$ & Plate stuck hard to mold face; chunks of green part occasionally stuck to mold wall. \\
\hline & $P P^{\star \star}$ & Excellent release of green plate from mold. \\
\hline & & 3 \\
\hline \multirow[t]{2}{*}{ Rough Aluminum } & F-57 & Stuck harder to mold face as compared with smooth aluminum; large chunks stuck to mold face. \\
\hline & PP & Excellent release. \\
\hline \multirow[t]{4}{*}{ is } & $606^{*}$ & Excellent release; very thin wet film (liquid, not slurry) at interface. \\
\hline & $1212^{*}$ & Excellent release; very thin wet film at interface. \\
\hline & $A Z N^{*}$ & Part bonded strongly to the mold face. Partial tearing of green plate was observed. \\
\hline & FF-19R* & Excellent release at interface but a thin adherent (powder) coating on the mold face. \\
\hline \multirow{3}{*}{$\begin{array}{l}\text { Smooth Anodized } \\
\text { Aluminum }\end{array}$} & $F-57$ & Considerable sticking of green plate to mold face in several spots. \\
\hline & PP & Excellent release; slightly wet (liquid) at mold face. \\
\hline & 606 & Excellent release; very thin wet (liquid) film at interface. \\
\hline ses & 1212 & Excellent release; very thin wet (liquid) film at interface. \\
\hline & AZN & Good release but a thin adherent powder coating on mold face. \\
\hline & FF-19R & Excellent release, no adherent coating on mold face. \\
\hline
\end{tabular}




\begin{tabular}{|c|c|c|}
\hline Substrate Surface & $\begin{array}{l}\text { Mold } \\
\text { Release }\end{array}$ & Interaction \\
\hline \multirow{6}{*}{$\begin{array}{l}\text { Rough Anodized } \\
\text { Aluminum }\end{array}$} & $\mathrm{F}-57$ & Some sticking but no wet interfacial film. \\
\hline & PP & Excellent release, mold face fell away from part. \\
\hline & 606 & Excellent release; very thin (liquid) film at interface. \\
\hline & 1212 & Excellent release; very thin (liquid) film at interface. \\
\hline & $A Z N$ & Good release but a thin wet coating (liquid) on mold face. \\
\hline & FF-19R & Excellent release. \\
\hline \multirow[t]{6}{*}{ Plexiglass } & F-57 & Lot of sticking of plate to mold face, ungelled layer present. \\
\hline & PP & Also a wet, ungelled layer at interface between part and mold. No sticking. \\
\hline & 606 & Poor gelation; required an extra $30 \mathrm{~min}$ in the oven (60 min total). \\
\hline & 1212 & Poor gelation; required an extra $30 \mathrm{~min}$ in the oven (60 min total). \\
\hline & AZN & $\begin{array}{l}\text { Very good removal of green plate from face of the mold, even though a thin ungelled layer existed at } \\
\text { the interface. }\end{array}$ \\
\hline & FF-19R & $\begin{array}{l}\text { Very good removal of green plate from face of the mold, even though a thin ungelled layer existed at } \\
\text { the interface. }\end{array}$ \\
\hline \multirow[t]{6}{*}{ Lexan } & $F-57$ & A wet, thin ungelled layer at the large mold face of the plate \\
\hline & PP & A wet, thin ungelled layer at the large mold face of the plate. \\
\hline & 606 & Ungelled layer on both large mold faces. \\
\hline & 1212 & Ungelled layer on both large mold faces. \\
\hline & AZN & There was an ungelled layer on mold face of the plate. \\
\hline & FF-19R & $\begin{array}{l}\text { There was an ungelled layer on mold face of the plate. FF-19R coat released easier than AZN-coated } \\
\text { face. }\end{array}$ \\
\hline
\end{tabular}




\begin{tabular}{|l|l|l||}
\hline Substrate Surface & $\begin{array}{l}\text { Mold } \\
\text { Release }\end{array}$ & Interaction \\
\hline Glass & F-57 & Uniform wetting of ungelled layer which spread over the large mold face of the green plate. \\
\hline & PP & The PP coating caused ungelled layer to "breakup" on the large mold face. \\
\hline & 606 & Good release but particle sticking at upper edge; possible drying problem. \\
\hline & 1212 & Excellent release. \\
\hline & AZN & Excellent release and no ungelled layer on mold face of sample. \\
\hline & FF-19R & Excellent release and no ungelled layer on mold face of sample. \\
\hline
\end{tabular}

* Axel Plastics Research Laboratories, Inc., Woodside, NY

** Polyester Parfilm, Price-Driscoll Corp., Waterford,. CT 
C/ORNL 95-0389

\section{INTERNAL DISTRIBUTION}

1. A. J. Luffman, Office of Science and Technology Partnerships, MS-6416, 5002

2. C. A. Valentine, Office of Technology Transfer Business Office, MS-8242, 701 SCA

3-4.D. R. Hamrin, Laboratory Records-RC, MS-6285, 4500N

5. Pete Angelini, 4515, MS-6065

6. Ron Bradley, 4500S, MS-6161

7. E. E. Bloom, $4500 \mathrm{~S}, \mathrm{MS}-6132$

8. Arvid Pasto, 4515 , MS- 6062

9. Linda Horton, 4500 S, MS-6132

10. Mary H. Rawlins, DOE/ORO, 4500 N, MS-6269

11. Bob Lauf, 4508, MS-6085

12. Tony Schaffhauser, $4500 \mathrm{~N}, \mathrm{MS}-6186$

13. M. A. Janney, 4508 , MS 6087

\section{EXTERNAL DISTRIBUTION}

14. P. L. Gorman, Department of Energy, Oak Ridge Operations Office, P.O. Box 2008, Oak Ridge, TN 37831-6269

15. DOE Work for Others Office, MS G209, P.O. Box 2001, Room G209, Oak Ridge, TN 37831

16. Charles Sorrell, Office of Industrial Technologies, Energy Efficiency and Renewable Energy, Department of Energy, EE-23, 1000 Independence Avenue, SW, Washington, DC 20585

17. William Rhodes, Manager, Lighting Materials Research Department, Osram Sylvania Inc., 71 Cherry Hill Drive, Beverly, MA 01915-1068

18. DOE-ORO, Site Office, P. O. Box 2008, Oak Ridge, TN 37831-6269

29-20. U.S. DOE, Office of Scientific and Technical Information (2), P.O. Box 62, Oak Ridge, TN 37831 


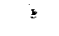

